УДК 378.011.3-051:373.3:004

DOI:

Іван Василиків, кандидат педагогічних наук, старший викладач кафедри математики, інформатики та методики їх викладання у початковій школі Дрогобицького державного педагогічного університету імені Івана Франка

\title{
ОБ’ЄКТИВНА НЕОБХІДНІСТЬ ВДОСКОНАЛЕННЯ ПІДГОТОВКИ ВЧИТЕЛЯ ПОЧАТКОВИХ КЛАСІВ У СФЕРІ ІНФОРМАЦІЙНИХ ТЕХНОЛОГІЙ В УМОВАХ РЕФОРМУВАННЯ ПОЧАТКОВОЇ ОСВІТИ
}

У статті визначено педагогічні умови, що сприяють ефективності прочесу формування інформаційноі компетентності майбутніх учителів початкової школи, а саме: створення у закладі вищої освіти інформаційно-педагогічного середовища, спрямованого на формування інформаційної компетентності майбутніх учителів початкової школи; активна участь їх у професійній діяльності з метою формування позитивної мотивації та методичного досвіду раціонального використання інформаційних технологій у професійно-методичній діяльності. Удосконалення змісту, форм, методів і прийомів, педагогічного та методичного забезпечення освітнього процесу у закладі вищої освіти, з метою формування інформаційної компетентності майбутніх учителів початкової школи.

Ключові слова: інформачійні технології; майбутній учитель початкової школи; компетентність; електронні освітні ресурси; презентації; молодші школярі.

Jim. 10.

Ivan Vasylykiv, Ph.D.(Pedagogy), Senior Lecturer of the Mathematics, Informatics and Methods of Teaching in Primary School Department, Drohobych Ivan Franko State Pedagogical University

\section{OBJECTIVE NECESSITY OF IMPROVEMENT OF TRAINING OF PRIMARY CLASS TEACHER IN THE FIELD OF INFORMATION TECHNOLOGIES IN THE CONDITIONS OF REFORMATION}

The article deals with the pedagogical conditions that contribute to the effectiveness of the process of formation of information competence of future primary school teachers, namely: creation in the institution of higher education of information and pedagogical environment aimed at the formation of information competence of future primary school teachers; their active participation in the professional activities in order to form a positive motivation and methodological experience of rational use of information technology in professional and methodological activities. The authors pays attention on the improving the content, forms, methods and techniques, pedagogical and methodological support of the educational process in higher education, in order to form the information competence of future primary school teachers.

The urgency of modern informatization determines the need for a comprehensive solution to the scientific and pedagogical problem of creating a professionally oriented information and educational environment in different areas: higher, vocational and secondary education, with appropriate adaptation of electronic educational resources (EER) to the personal needs of schoolchildren and students, as well as requests for advanced training or retraining of those who have some practical development experience.

The purpose of creating EER is to modernize the education, content educational space, ensuring equal access for participants of educational process to high-quality educational and methodical materials, regardless of their place of residence and form of education, created on the basis of information technology.

Keywords: information technologies; future primary school teacher; competence; electronic educational resources; presentations; junior high school students.

П остановка проблеми. У процесі формування інформаційноїкомпетентності професійноїпідготовкимайбугніх вчителів початкових класів існує ряд вимог: зростанням потреб суспільства у вчителях здатних впроваджувати сучасні інформаційно-комунікаційні технології, недостатньо розроблені теоретико-методичні засади їх підготовки у закладах вищої педагогічної освіти; зростання вимог до рівня інформаційної компетентності майбутніх учителів початкової школи та недостатньою розробленістю теоретикометодологічних засад їх формування.

Аналіз останніх досліджень і публікацій. Теоретичні засади впровадження IT в освітній процес початкової школи досліджували В. Андрісвська [3], Г. Ломаковська [6], Ю. Первін [9], О. Снігур [10] та ін.; положення щодо формування інформаційної компетентності 


\section{ОБ'ЄКТИВНА НЕОБХІДНІСТЬ ВДОСКОНАЛЕННЯ ПІДГОТОВКИ ВЧИТЕЛЯ ПОЧАТКОВИХ КЛАСІВ У СФЕРІ ІНФОРМАЦІЙНИХ ТЕХНОЛОГІЙ В УМОВАХ РЕФОРМУВАННЯ ПОЧАТКОВОЇ ОСВІТИ}

майбутніх учителів початкових класів сформулювали В. Барановська [4], В. Коткова [5], I. Онищенко [7], Л. Петухова [8] та ін.

Мета статті: полягає в дослідженні рівня сформованості інформаційної компетентності майбутніх учителів початкової школи.

Виклад основного матеріалу. Вважається, що інформатизація вітчизняної системи освіти почалася з 1985 р., коли було прийнято рішення про направлення в сферу освіти перших персональних ЕОМ і про введення до програми середньої школи навчального предмету “Основи інформатики та обчислювальної техніки”. Однією 3 головних цілей вивчення цього предмету в школах було формування в учнів комп'ютерної грамотності, під якою розумілося володіння навичками розв'язання завдань 3 допомогою EOM, а також розуміння основних ідей інформатики та ролі інформаційних -технологій у розвитку суспільства.

Історія інформатизації вітчизняної системи освіти за значно невеликий проміжок часу пережила кілька етапів, постійно змінювалася, удосконалювалася, структурувалися їі цілі і завдання. Усі реформи системи освіти й сам процес іiї інформатизації не могли не торкнутися і початкової школи. Інформатизація позначена такими напрямами:

- застосування електронних освітніх ресурсів при навчанні учнів;

- навчання молодших школярів практичних навичок використання засобів IT для розв'язання комунікативних і пізнавальних завдань;

- викладання пропедевтичного курсу інформатики у початковій школі;

- розвиток інформаційно-освітнього середовища початкової школи.

Охарактеризуємо більш детально кожний з перерахованих напрямів.

Поняття ЕОР в Україні стало загальновживаним. 3 публікацією “Положення про ЕОР” закріпилося його базове визначення в Україні: “Електронні освітні ресурси (ЕОР) - вид засобів освітньої діяльності (навчання та ін.), що існують в електронній формі, є сукупністю електронних інформаційних об'єктів (документів, документованих відомостей та інструкцій, інформаційних матеріалів, процесуальних моделей та ін.), які розташовуються і подаються в освітніх системах на запам'ятовуючих пристроях електронних даних" [1].

Під електронними освітніми ресурсами (ЕОР) будемо розуміти навчальні матеріали, для виконання яких використовуються електронні пристрої. Незважаючи на різноманіття різних текстових і гіпертекстових електронних матеріалів, найбільшу популярність в початковій освіті завоювали мультимедійні ЕОР, що зумовлено психолого-педагогічними закономірностями навчальної-діяльності в початковій школі.

У цьому аспекті становить інтерес дослідження О. М. Снігур [10], в якому узагальнені дидактичні особливості застосування елек-тронних освітніх ресурсів на різних етапах уроку в початковій школі. Спираючись на результати означеного дослідження, можна виділити найбільш продуктивні прийоми використання ЕОР для розв'язання конкрет-них дидактичних завдань 3 урахуванням психологопедагогічних особливостей молодших школярів: індивідуальна робота з електронним навчальним посібником 3 метою навчання, самоконтролю, дослідження, створення освітнього продукту та ін.; робота з електронними освітніми ресурсами на уроках для отримання консультативної допомоги, з метою розвитку навичок спільної навчальної діяльності, взаємодопомоги, відповідальності за загальний результат та ін.; використання електронних ресурсів як джерела навчальної інформації при роботі в групах; застосування можливостей IT для оформлення та подання результатів індивідуальної або групової проєктної діяльності молодших школярів; естафета, рольова гра, одним з етапів якої $\epsilon$ виконання інтерактивних завдань електронного навчального посібника, що стимулює пізнавальну активність молодших школярів; колективноіндивідуальна робота та індивідуальне виконання школярем інтерактивного завдання електронного навчального посібника. Згідно $з$ дослідженням В. Коткової [5] і численними публікаціями стосовно практичного досвіду використання ЕОР освітньої діяльності. можна стверджувати, що використання електронних освітніх ресурсів дає змогу підвищити ефективність процесу навчання молодших школярів, якщо дотримуватися вікових та психолого-педагогічних особливостей означеного віку.

EОР можуть бути класифіковані за рядом факторів, наприклад:

1) особливістю діяльності учня при використанні EOP;

2) характером взаємодії вчителя і учня в умовах використання ЕОР;

3) спрямованістю на навчальний предмет;

4) способом розповсюдження або створення.

Існує класифікація ЕОР:

- Пояснювально-ілюстративні ЕОР, які служать засобом візуалізації викладеного вчителем матеріалу. Найбільш поширеним видом таких ЕОР виступають різноманітні презентації. 


\section{ОБ'ЄКТИВНА НЕОБХІДНІСТЬ ВДОСКОНАЛЕННЯ ПІДГОТОВКИ ВЧИТЕЛЯ ПОЧАТКОВИХ КЛАСІВ У СФЕРІ ІНФОРМАЦЙНИХ ТЕХНОЛОГІЙ В УМОВАХ РЕФОРМУВАННЯ ПОЧАТКОВОӤ ОСВІТИ}

- Практичні ЕОР, які надають учню можливість відпрацювання та закріплення навчального матеріалу. До них можна віднести розвивальні та імітаційні ігри, предметноорієнтовані середовища і ін.

- Контролюючі ЕОР, які дають можливість проконтролювати й оцінити результативність навчальної діяльності школяра. Найбільш поширені з них - різноманітні тести.

Використання ЕОР у навчальному процесі сприяє реалізації різноманітних варіантів взаємодії вчителя і учня

1. Використання ЕОР на уроці вчителем при відсутності самостійного взаємодії учня з його змістом. 2. Використання ЕОР на уроці вчителем і взаємодія учня з його змістом під керівництвом учителя. 3. Використання ЕОР учням у процесі самостійної роботи згідно з рекомендаціями вчителя. 4. Використання ЕОР учнем на уроці й у позаурочній діяльності згідно 3 його індивідуальним вибором і рекомендаціями вчителя. 5. Використання ЕОР у позаурочній діяльності при домінуючій ролі учня.

За спрямованістю ЕОР на навчальний предмет можна розрізняти:

1) монопредметні ЕОР;

2) міждисциплінарні ЕОР, які дають змогу інтегрувати в кілька предметів;

3) ЕОР, які орієнтовані на формування у молодших школярів універсальних навчальних дій.

За способом розповсюдження або створення ЕОР поділяються на:

1) ЕОР, що входять до стандартних навчальнометодичних комплексів 3 навчального курсу або освітньою програмою;

2) ЕОР, що є частиною єдиної кількості лекцій цифрових освітніх ресурсів, розробленої у рамках програми інформатизації і підтримує навчальні предмети освітнього стандарту початкової школи;

3) ЕОР, розроблені авторськими колективами або окремими вчителями.

У чинному шкільному освітньому стандарті [2] початкової школи відведена величезна роль у розвитку інформаційної грамотності учнів як важливої складової універсальних навчальних дій. На підставі цього, в освітній програмі початкової школи міститься підпрограма формування інформаційно-комунікаційної компетентності (ІКК) учнів, яка характеризує IT як інструментарій універсальних навчальних дій. Зміст, обгрунтованість і системність запропонованої програми розвитку ІКК молодших школярів суттєво перекриває всі раніше викладені програми формування комп'ютерної або інформаційної грамотності в рамках окремих курсів початкової школи. Тому для вивчення можливостей розвитку і утримання IКК молодших школярів обмежимося розглядом цієї програми. Особливе значення у ній надається розвитку в учнів початкових класів навчальної ІКК, яка визначається як “здатність вирішувати навчальні завдання з використанням інструментів ІКТ та джерел інформації у відповідності з віковими потребами і можливостями молодшого школяра".

За твердженням В. Барановської [3], компетентність - сукупність знань та вмінь, необхідних для ефективної професійної діяльності; рівень оволодіння певною діяльністю; здатність та вміння здійснювати необхідну діяльність; спроможність і готовність застосовувати знання, уміння і особисті якості для успішної діяльності в певній галузі; вміння аналізувати, передбачати наслідки професійної діяльності; спеціальні вміння для виконання певних професійних обов'язків відповідно до певних професійних стандартів.

Основний зміст програми “Формування інформаційно-комунікаційної компетентності учнів" реалізується засобами різних навчальних предметів початкової школи. При плануванні змісту освіти молодших школярів в галузі інформаційних технологій важливо враховувати те, щоб формування того чи того елемента ITкомпетентності було безпосередньо пов'язане 3 його застосуванням.

Тим самим забезпечується:

- мотивація застосування засобів IT відповідно до мети навчання предмету;

- вбудований контроль результатів освоєння IT;

- підвищення ефективності застосування IT у цьому предметі;

- формування цифрового портфоліо учня 3 предмету, необхідного для оцінювання результатів освоєння цього предмету.

Підпрограма формування IКК $є$ широкою i включає в себе всі можливі аспекти роботи 3 інформацією різної природи: тексти на рідній та іноземних мовах; числові дані, отримані в результаті вимірювання або обчислення; власні комп'ютерні рисунки, слайди і цифрові фотознімки, аудіо та відеозаписи; діаграми, графіки. Особливе значення у програмі відводиться прищеплюванню культури роботи із засобами IT, спираючись при цьому на ергономічні і здоров'язберігаючі технології [5].

Важливим для будь-якої людини $\epsilon$ забезпечення власної інформаційної безпеки. Молодші школярі цілком готові до вивчення деяких найпростіших принципів означеного виду безпеки, котрі можуть істотно полегшити їхню 


\section{ОБ’ЄКТИВНА НЕОБХІДНІСТЬ ВДОСКОНАЛЕННЯ ПДГОТОВКИ ВЧИТЕЛЯ ПОЧАТКОВИХ КЛАСІВ У СФЕРІ ІНФОРМАЦЙНИХ ТЕХНОЛОГІЙ В УМОВАХ РЕФОРМУВАННЯ ПОЧАТКОВОӤ ОСВІТИ}

навчальну діяльність. Для цього необхідно розуміння учнями файлової організації зберігання і розповсюдження інформації. Учні молодших класів оволодівають навичками копіювання i збереження файлів, вчаться використовувати для зберігання інформації зовнішні носії, наприклад, флешки, здійснюють упорядкування файлів усередині папок.

У дисертаційному дослідженні В. Андрієвської порушено проблему підготовки майбутнього вчителя початкової школи до використання інформаційно-комунікаційних технологій у професійній діяльності (Харків, 2019 р.) [3] та на цій основі представлено авторську модель підготовки майбутнього вчителя початкової школи до використання ІКТ у професійній діяльності.

Практикою доведено, що найбільш популярним навчальним продуктом у початковій школі $€$ комп'ютерна презентація. Наочність створення презентацій і ефектність одержуваного результату роблять таку роботу цілком доступною і зрозумілою для учнів навіть першого класу. Надалі робота 3 презентацією може бути диференційована і заглиблена, при цьому з'являються презентації-підручники, презентаціїкаталоги, презентації, бази даних і т. д. Це можливо завдяки додаванню на екран зображення, звуку, тексту, використання гіперпосилань і керуючих об'єктів. Презентація може виступати основним доповнювачем усного повідомлення; для цього учневі необхідно навчитися виділяти в тезовій формі основні думки викладеного матеріалу.

Однією з важливих відмінних характеристик освіченості учня $є$ його вміння ефективно організовувати пошук необхідної інформації. Розвиток пошукової інформаційної діяльності починається ще в дошкільному віці розвивається протягом усього освітнього процесу, а вже в початковій школі набуває рис системності. У зв'язку з цим, дуже важливим $є$ навчання учнів засобів інформаційного пошуку в електронних джерелах, у тому числі і в мережі Інтернет. Для цього необхідне первинне ознайомлення пошуковими системами й інформаційними структурами (база даних, таблиці, діаграми та ін.), а так само навчання на конкретних прикладах формулювати пошуковий запит, інтерпретувати знайдену інформацію та оцінювати ії адекватність

Значущим аспектом соціалізації людини є іiі життєві можливості. У початковій школі закономірно виникає необхідність освоєння сучасних і популярних засобів дистанційного контакту. Сьогодні такими засобами можна назвати електронну пошту, чат, форум, аудіо- та відеоконференції і т.д. Від учня вимагається вміння відправляти письмове або мультимедійне повідомлення в інформаційно-комунікаційному освітньому середовищі, фіксувати хід і результат колективного обговорення на екрані, у файлах, вести щоденник спілкування, організовувати соціальну взаємодію всередині колективу.

Особливе значення у розвитку та навчанні молодших школярів відіграють процеси алгоритмізації та моделювання. Використання інструментів IT дає змогу більш продуктивно $\mathrm{i}$ творчо організувати роботу школярів, пов'язану 3 плануванням і проведенням досліджень об'єктів і процесів реального світу. При цьому школяр може виступати як дослідником навколишньої дійсності, що реалізує відповідний уже наявний план, фіксуючи і інтерпретуючи отриману інформацію, так і учасником віртуального експерименту, дослідником і керівником штучних лабораторій і конструктором.

Висновки. Таким чином, зміст навчання молодших школярів у галузі використання IT для розв'язання комунікативних і пізнавальних завдань відображає стан і рівень інформаційних процесів у суспільстві. При цьому шкільна освіта, орієнтуючись на концепцію розвитку та освіти дитини, прагне адаптувати сучасні соці-альні інформаційні технології до вікових можливостей і дидактичних потреб дітей молодшого шкільного віку.

\section{ЛІТЕРАТУРА}

1. Про інформацію: Закон України від 2 жовт. 1992 р. № 2657-XII (в ред. Закону України від 23 черв. 2005 р. №. 2707-IV).

2. Постанова Кабінету Міністрів від 21.02.2018p. №87 “Про затвердження Державного стандарту початкової освіти”. “Державний стандарт початкової освіти".

3. Андрієвська В. М., Олефіренко Н. В. Мультимедійні технології у початковій ланці освіти. Інформаційні технологї $і$ засоби навчання. 2010. № 2. С. 16.

4. Барановська В. М. Сутність поняття “система інформатичних компетентностей”. Науковий часопис НПУ імені М.П. Драгоманова. Київ : НПУ імені М. П. Драгоманова, 2014. Вип. 14 (21). C. $48-59$.

5. Коткова В.В. Педагогічні умови формування інформатичних компетентностей студентів майбутніх учителів початкових класів. Інформаційні технології $i$ засоби навчання. 2011. № 2. URL : http://www.journal.iitta.gov.ua (дата звернення: 22.07.2017) 


\section{ОБ'ЄКТИВНА НЕОБХІДНІСТЬ ВДОСКОНАЛЕННЯ ПІДГОТОВКИ ВЧИТЕЛЯ ПОЧАТКОВИХ КЛАСІВ У СФЕРІ ІНФОРМАЦЙНИХ ТЕХНОЛОГІЙ В УМОВАХ РЕФОРМУВАННЯ ПОЧАТКОВОЇ ОСВІТИ}

6. Ломаковська Г. В., Проценко Г. О. Науковопедагогічний проект “ІТ освіта” як складова системи підготовки фахівців для забезпечення потреб ІТ-індустрії України. Комп 'ютер у школі mа сім'ї. 2012. № 2. С. 28-29. URL :http:// nbuv.gov.ua/UJRN (дата звернення : 23.12.2018)

7. Онищенко I. В. Вплив інформатизації вищої педагогічної освіти на процес формування інформатичних компетентностей майбутніх учителів початкових класів. Вісник Черкаського університету. Сер. : Педагогічні науки. 2016. № 7. C. 31-37. URL : http://ped-ejournal.cdu.edu.ua/ article/view/1592 (дата звернення : 17.05.2016).

8. Петухова Л. С., Бальоха А. С. Інформаційнокомунікаційне педагогічне середовище в контексті професійної підготовки майбутніх учителів початкової школи. Science and Education in New Dimension. Pedagogy and Psychology. 2016. IV (39). Issue 79. P. 60-64.

9. Первин Ю.А. Курс "Информационная культура" и начальная школа. Компьютерные инструменты в образовании. 1998. № 6. С. 511.

10. Снігур О.М. Формування вмінь використовувати засоби інформаційних технологій у майбутній професійній діяльності вчителя початкової школи: автореф. дис. ... канд. пед. наук : 13.00.09. Київ, $2007.22 \mathrm{c}$.

\section{REFERENCES}

1. Pro informatsiiu: Zakon Ukrainy vid 2 zhovt. 1992 r. № 2657 - XII (v red. Zakonu Ukrainy vid 23 cherv. 2005 r. No. 2707-IV). [About information: Law of Ukraine of October the $2^{\text {nd }} .1992$ No. 2657-XII (as amended by the Law of Ukraine of June the $23^{\text {rd }}$, 2005 No. 2707-IV].[in Ukrainian].

2. Postanova Kabinetu Ministriv vid 21.02.2018r. №87 "Pro zatverdzhennia Derzhavnoho standartu pochatkovoi osvity" [Resolution of the Cabinet of Ministers of February the $21^{\text {st }}, 2018$ №87 “On approval of the State standard of primary education"]. "State standard of primary education". [in Ukrainian].

3. Andriievska, V. M. \& Olefirenko, N. V. (2010). Multymediini tekhnolohii u pochatkovii lantsi osvity [Multimedia technologies in primary education]. Information technologies and teaching aids, no. 2. p. 16. [in Ukrainian].

4. Baranovska, V. M. (2014). Sutnist poniattia "systema informatychnykh kompetentnostei" [The essence of the concept o "system of information competencies"]. Scientific journal of NPU named after Mykhaylo Drahomanov. Kyiv, Vol. 14 (21). pp. 48-59. [in Ukrainian].

5. Kotkova, V.V. (2011). Pedahohichni umovy formuvannia informatychnykh kompetentnostei studentiv - maibutnikh uchyteliv pochatkovykh klasiv [Pedagogical conditions for the formation of information competencies of students - future primary school teachers]. Information technologies and tools. No. 2. Available at : http:// www.journal.iitta.gov.ua (accessed 22 July 2017). [in Ukrainian].

6. Lomakovska, H. V. \& Protsenko, H. O. (2012). Naukovo-pedahohichnyi proekt "IT osvita" yak skladova systemy pidhotovky fakhivtsiv dlia zabezpechennia potreb IT-industrii Ukrainy [Scientific and pedagogical project "IT education" as a component of the training system to meet the needs of the IT industry of Ukraine]. Computer at school and family. No. 2. pp. 28-29. Available at: http:// nbuv.gov.ua/UJRN (accessed 23 Dec.2018) [in Ukrainian].

7. Onyshchenko, I. V. (2016). Vplyv informatyzatsii vyshchoi pedahohichnoi osvity na protses formuvannia informatychnykh kompetentnostei maibutnikh uchyteliv pochatkovykh klasiv [Influence of informatization of higher pedagogical education on the process of formation of information competencies of future primary school teachers]. Bulletin of Cherkasy University. Ser. : Pedagogical sciences. No. 7. pp. 31-37. Available at: http://pedejournal.cdu.edu.ua/article/view/1592 (accessed 17 May. 2016). [in Ukrainian].

8. Petukhova, L. Ye. \& Balokha, A. S. (2016). Informatsiino-komunikatsiine pedahohichne seredovyshche $\mathrm{v}$ konteksti profesiinoi pidhotovky maibutnikh uchyteliv pochatkovoi shkoly [Information and communication pedagogical environment in the context of professional training of future primary school teachers]. Science and Education in New Dimension. Pedagogy and Psychology. IV (39). Issue 79. pp. 60-64. [in Ukrainian].

9. Pervin, Yu.A. (1998). Kurs "Informatsionnaya kultura" i nachalnaya shkola ["Information culture" and primary school]. Computer tools in education. No. 6. pp. 5-11. [in Ukrainian].

10. Snihur, O. M. (2007). Formuvannia vmin vykorystovuvaty zasoby informatsiinykh tekhnolohii u maibutnii profesiinii diialnosti vchytelia pochatkovoi shkoly [Formation of skills to use information technology tools in the future professional activity of an elementary school teacher]. Extended abstract of candidate's thesis. 22 p. [in Ukrainian].

Стаття надійшла до редакції 22.09.2021 